\title{
Response of Transplanted Paddy to Foliar Spray of Silicon in South Gujarat, India
}

\author{
K. A. Shah ${ }^{1 *}$, Prabhu Nayaka ${ }^{2}$ and A. N. Lad $^{3}$ \\ ${ }^{1}$ Scientist (Agronomy), KVK, NAU, Navsari, Gujarat, India \\ ${ }^{2}$ (Plant protection), KVK, NAU, Navsari, Gujarat, India \\ ${ }^{3}$ (Soil Science \& Agricultural chemistry), KVK, NAU, Navsari, Gujarat, India \\ *Corresponding author
}

\begin{abstract}
A B S T R A C T
A field experiment was conducted for three consecutive years at NAU, Navsari, during the year 2015-16, 2016-17and 2017-18 to study the effect of foliar spray of potassium silicate on growth and yield of paddy. Seven treatment of potassium silicate as a foliar spray $\left(\mathrm{T}_{1}\right.$ : control, $0 . \mathrm{T}_{2}: 0.5 \%$ potassium silicate at tillering and $\mathrm{PI}, \mathrm{T}_{3}: 0.5 \%$ potassium silicate at tillering, $\mathrm{PI}$ and grain formation stage, $\mathrm{T}_{4}$ : $1.0 \%$ potassium silicate at tillering and PI, $\mathrm{T}_{5}: 1.0 \%$ potassium silicate at tillering, $\mathrm{PI}$ and grain formation stage, $\mathrm{T}_{6}: 1.5 \%$ potassium silicate at tillering and PI and $\mathrm{T}_{7}: 1.5 \%$ potassium silicate at tillering, $\mathrm{PI}$ and grain formation stage) were tested in complete randomize design with four replication. The various growth and yield attributes viz., panicle length, panicle weight, number of grain per panicle and weight of grain per panicle, grain and straw yield, as well as gross return, net return and $\mathrm{BC}$ ratio were recorded significantly superior over control. under the foliar spray of potassium silicate @ 1.0 percent at tillering, panicle initiation and grain formation stage.
\end{abstract}

\section{Keywords}

Silicon, Rice, Grain yield, Potassium silicate

Article Info

Accepted:

10 April 2020

Available Online:

10 May 2020

\section{Introduction}

Rice (Oriza sativa L.) is the most important food crop of India. In last few years rice yield has been found diminishing and nutritional imbalance has been reported as one of major concerned. In a more specific study of nutrients; the micronutrients now have been found equally important as macronutrients although they are required in a minute quantity. Balancing the micronutrients for rice cultivation enhanced the quality and yield $\mathrm{Ma}$ et al., (2007).

Among all the micronutrients assimilated by plants, silicon alone is consistently present at concentrations similar to those of the macronutrients. 
Micronutrients such as silicon ( $\mathrm{Si}$ ) are the most important for healthy and competitive growth of all cereals including rice in Asia (Brunings et al., 2009). Silicon is the second most abundant element in the soil after oxygen. Though the solubility of silicate minerals vary under different soil and environmental conditions, however its concentrations in soli solutions range from 0.1 to $0.6 \mathrm{mM}$ (Joseph, 2009). Its concentrations in different plants range from $0.1 \%$ (similar to $\mathrm{P}$ and S) to more than $10 \%$ of whole plant dry matter (Epstein, 1999). Plants growing under natural conditions do not appear to suffer from Si deficiencies. However, Si-containing fertilizers are routinely applied to several crops for increasing the crop yield and quality.

Although silicon has not been considered important for vegetative growth, but it aids the plant in healthy development under stresses in different grasses especially in rice. Research evidences proved that adequate uptake of silicon ( $\mathrm{Si}$ ) can increase the tolerance of agronomic crops especially rice to both abiotic and biotic stress ( $\mathrm{Ma}$ and Takahashi, 2002). Plant tissue analysis has revealed the optimum amount of silicon is necessary for cell development and differentiation (Liang et al., 2005).

Increased Si supply improves the structural integrity of crops and may also improve plant tolerance to diseases, drought and mineral toxicities (Epstein, 1999; Richmond and Sussman, 2003; Ma et al., 2004). Many scientists working on role of silicon in plant growth have concluded that reduced amount of silicon in plant develops necrosis, disturbance in leaf photosynthetic efficiency, growth retardation and reduce grain yield in cereals (Shashidhar et al., 2008). Foliar fertilization or foliar feeding entails the application of nutrients via spraying to plant leaves and stems and their absorption at those sites. Foliar fertilizers are usually applied along with agricultural pesticides to lower the cost of application. Although few studies have been confirm the benefits of the use of silicon as amendments through foliar applications. There is no user friendly commercial product of silicon for foliar applications and very limited information is available on yield parameters and uptake of nutrient elements, particularly in rice.

Under changing socio-economic conditions all around the world, reduction in paddy yield is not affordable by the agricultural system. Applications of major nutrients are already in practice at optimum level but yield gap is still present. Therefore, present study was designed to study the effect of foliar application of different concentrations of silicon on rice yield under the south Gujarat conditions. The main objective was to evaluate the effect of foliar application of silicon on yield of rice.

\section{Materials and Methods}

The Field experiment was conducted at Krishi Vigyan Kendra Farm, Navsari Agricultural University, Navsari for the south Gujarat region during kharif season of three consecutive year 2015-16, 2016-17 and 201718. The experimental site is located at 20.94$76^{\circ} \mathrm{N}$ latitude and $72.95-20^{\circ} \mathrm{E}$ longitudes with an altitude of $9 \mathrm{~m}$ mean sea level. The soil of the experiential plots was clay in texture having medium to poor drainage, alkaline in reaction $(\mathrm{pH}=7.86)$, low in available nitrogen $(512 \mathrm{~kg} / / \mathrm{ha})$ and medium in available phosphorus ( $49 \mathrm{~kg} / \mathrm{ha})$ and potash (268 kg/ha). Total seven treatments consisting of $\mathrm{T}_{1}$ : control, $\mathrm{T}_{2}: 0.5 \%$ potassium silicate at tillering and panicle initiation stage (PI), $\mathrm{T}_{3}$ $: 0.5 \%$ potassium silicate at tillering, PI and grain formation stage, $\mathrm{T}_{4}: 1.0 \%$ potassium silicate at tillering and PI, $\mathrm{T}_{5}: 1.0 \%$ potassium silicate at tillering, PI and grain formation 
stage, $\mathrm{T}_{6}: 1.5 \%$ potassium silicate at tillering and $\mathrm{PI}$ and $\mathrm{T}_{7}: 1.5 \%$ potassium silicate at tillering, PI and grain formation stage were tested in complete randomize design with four replication. Paddy variety "GNR-3" seeds were used for the raising the nursery. Twenty five days old seeding was transplanted at a distance of $20 \times 15 \mathrm{~cm}$ in previously puddle field in the third week of July during all the three years.

The recommended dose of $10 \mathrm{t}$ FYM/ha was applied at the time of land preparation and entire dose of phosphorus $\left(30 \mathrm{~kg} \mathrm{P}_{2} \mathrm{O}_{5} / \mathrm{ha}\right)$ and 40 per cent dose of nitrogen $(40 \mathrm{~kg} \mathrm{~N} / \mathrm{ha})$ applied as a basal application just before transplanting and remaining 40 per cent (40 $\mathrm{kg} \mathrm{N} / \mathrm{ha}$ ) and 20 per cent ( $20 \mathrm{~kg} \mathrm{~N} / \mathrm{ha}$ ) dose of nitrogen were applied at tillering and panicle initiation stage, respectively.

Foliar spray of silicon was applied through the potassium silicate as per the treatments. Urea and die ammonium phosphate were taken as fertilizer sources for $\mathrm{N}$ and $\mathrm{P}$, respectively. All the plant protection measures were taken as per the recommendation in rice crop. The annual rainfall of 1209,1430 and $1318 \mathrm{~mm}$ were received throughout the crop growth period during the year 2015-16, 2016-17 and 201718 , respectively. The results were analysis statistically to draw suitable interference as per the standard ANOVA techniques suggested by Gomez and Gomez (1984).

\section{Results and Discussion}

\section{Effect on growth and yield attributes}

The data show in Table-1 clearly indicated that there was none significant difference found in growth parameter due to varying levels of foliar application of potassium silicate at different crop growth stages. The growth attributes viz. plan height $(\mathrm{cm})$ and effective tillers $/ \mathrm{m}^{2}$ were found numerically maximum with the foliar spray of 1.0 and 1.5 per cent potassium silicate at tillering, panicle initiation (PI) and grain formation stage, respectively. There were 5.15 and 9.65 per cent increase in plant height and effective tillers $/ \mathrm{m}^{2}$ under the foliar application of 1.0 and 1.5 per cent potassium silicate at tillering, PI and grain formation stage. Similar types of results were also reported by Singh and Singh (2005), Ahmad et al., (2013).

Yield attributing characters viz, panicle length, panicle weight, number of grain per panicle and weight of grain per panicle were significantly influenced by different levels of potassium silicate foliar spray. Foliar spray of potassium silicate @ 1.0 percent at tillering, PI and grain formation stages was recorded remarkably higher panicle length $(24.03 \mathrm{~cm})$ and number of grain per panicle (154.42) over the control and $0.5 \%$ potassium silicate at tillering and PI stages. These finding are in accordance with Rodriguez et al., (2003) and Mobasser et al., (2008).

Panicle weight $(5.87 \mathrm{~cm})$ was found significantly higher under the foliar spray of $1.5 \%$ potassium silicate at tillering and PI stage over rest of the treatments except, the foliar spray of 1.0 and 1.5 at tillering PI and grain formation stages. Significantly the highest weight of grain per panicle $(5.26 \mathrm{~g})$ was noticed due to foliar spray of $1.5 \%$ potassium silicate at tillering, PI and grain formation stage over all other treatments, except treatment $\mathrm{T}_{5}$ and $\mathrm{T}_{6}$.

The increase in panicle weight and grain weight per panicle due to application of potassium silicate might be because of silicon helps in uptake the other essential nutrients elements which play an important role in plant metabolic activity. Similar types of results were observed by Prakash et al., (2011). 


\section{Effects on yield}

The variation in grain yield (Table-2) and straw yield (Table-3) were found to be significant due to foliar spray of potassium silicate in all the individual years and in pooled analysis. Significantly higher grain yield of $4819,4706,4615$ and $4713 \mathrm{~kg} / \mathrm{ha}$ were produced during the year 2015-16, 2016-17, 2017-18 and in pooled results, respectively, due to foliar spray of potassium silicate @ 1.0 per cent at tillering, PI and grain formation stage over control and it was remain at par with the foliar spray of potassium silicate at $1.5 \%$ at tillering and PI stand as well as potassium silicate @ 1.5 at tillering, PI and grain formation stages. The percentage increase in grain yield under the different foliar spray treatment up to the tune of $18.06,15.88$ and 16.91 per cent under the treatments $\mathrm{T}_{5}, \mathrm{~T}_{6}$ and $\mathrm{T}_{7}$ over control on pooled bases, respectively. The increase in grain yield may be attributed to the reduction in per cent spikelet sterility, increase the rate of photosynthesis and thereby increased the growth and yield attributes and helps in reduction of incidence of pest and disease.

These results resemble to the findings reported by Mobasser et al., (2008), Malidareh et al., (2011) and Prakash et al., (2011). Foliar spray of potassium silicate @ 1.5 percent at tillering, PI and grain formation stages recorded remarkably higher straw yield of $6505,6559,6419$ and $6495 \mathrm{~kg} / \mathrm{ha}$ over rest of the treatments during the year 2015-16, 2016-17, 2017-18 and in pooled respectively, except control and treatment $\mathrm{T}_{2} \quad(0.5 \%$ potassium silicate at tillering and PI stages) in all the individual year and in pooled analysis.

Table.1 Effect of foliar spray of potassium silicate on growth and yields attributes of kharif rice (pooled data of three year)

\begin{tabular}{|c|c|c|c|c|c|c|}
\hline Treatments & $\begin{array}{c}\text { Plant } \\
\text { height } \\
(\mathbf{c m})\end{array}$ & $\begin{array}{l}\text { Effective } \\
\text { tillers/m } \mathbf{m}^{2}\end{array}$ & $\begin{array}{l}\text { Panicle } \\
\text { length } \\
\text { (cm) }\end{array}$ & $\begin{array}{l}\text { Panicle } \\
\text { weight } \\
\text { (g) }\end{array}$ & $\begin{array}{l}\text { No. of } \\
\text { grain / } \\
\text { panicle }\end{array}$ & $\begin{array}{l}\text { Wt. of } \\
\text { grain/ } \\
\text { panicle }(g)\end{array}$ \\
\hline$T_{1}:$ Control (No spray) & 120.22 & 169.51 & 21.49 & 4.80 & 127.50 & 4.17 \\
\hline $\begin{array}{c}\mathrm{T}_{2}: 0.5 \% \text { potassium silicate at } \\
\text { Tillering and PI stage }\end{array}$ & 121.71 & 178.06 & 22.21 & 5.00 & 132.25 & 4.30 \\
\hline $\begin{array}{l}\mathrm{T}_{3}: 0.5 \% \text { potassium silicate at } \\
\text { Tillering, PI and grain } \\
\text { formation stage }\end{array}$ & 123.69 & 179.17 & 22.80 & 5.22 & 132.17 & 4.48 \\
\hline $\begin{array}{c}\mathrm{T}_{4}: \mathbf{1 . 0} \% \text { potassium silicate at } \\
\text { Tillering and PI stage }\end{array}$ & 124.02 & 181.83 & 23.62 & 5.43 & 135.75 & 4.75 \\
\hline $\begin{array}{l}\mathrm{T}_{5}: \mathbf{1 . 0} \% \text { potassium silicate at } \\
\text { Tillering, PI and grain } \\
\quad \text { formation stage }\end{array}$ & 126.42 & 184.55 & 24.03 & 5.86 & 154.42 & 5.09 \\
\hline $\begin{array}{c}\mathrm{T}_{6}: \mathbf{1 . 5 \%} \text { potassium silicate at } \\
\text { Tillering and PI stage }\end{array}$ & 125.63 & 180.82 & 23.60 & 5.87 & 153.42 & 5.17 \\
\hline $\begin{aligned} \mathrm{T}_{7}: & 1.5 \% \text { potassium silicate at } \\
& \text { Tillering, PI and grain } \\
& \text { formation stage }\end{aligned}$ & 126.27 & 185.86 & 23.85 & 5.84 & 150.92 & 5.26 \\
\hline S. Em. \pm & 2.24 & 4.47 & 0.45 & 0.14 & 3.81 & 0.14 \\
\hline C. D. at $5 \%$ & NS & NS & 1.28 & 0.40 & 10.77 & 0.39 \\
\hline C.V. \% & 6.26 & 8.60 & 6.81 & 9.07 & 9.37 & 9.98 \\
\hline YxT & NS & NS & NS & NS & NS & NS \\
\hline
\end{tabular}


Table.2 Grain yield of kharif rice as influenced by foliar spray of potassium silicate

\begin{tabular}{|c|c|c|c|c|}
\hline \multirow[t]{2}{*}{ Treatments } & \multicolumn{4}{|c|}{ Grain Yield (kg/ha) } \\
\hline & 2015-16 & 2016-17 & 2017-18 & Pooled \\
\hline $\mathbf{T}_{1}:$ Control (No spray) & 4034 & 4072 & 3868 & 3992 \\
\hline $\begin{array}{l}T_{2}: 0.5 \% \text { potassium silicate at Tillering } \\
\text { and PI stage }\end{array}$ & 4259 & 4280 & 3981 & 4173 \\
\hline $\begin{array}{l}\mathrm{T}_{3}: 0.5 \% \text { potassium silicate at Tillering, } \\
\mathrm{PI} \text { and grain formation stage }\end{array}$ & 4275 & 4396 & 4187 & 4286 \\
\hline $\begin{array}{l}T_{4}: 1.0 \% \text { potassium silicate at Tillering } \\
\text { and PI stage }\end{array}$ & 4451 & 4429 & 4292 & 4391 \\
\hline $\begin{array}{l}T_{5}: 1.0 \% \text { potassium silicate at Tillering, } \\
\text { PI and grain formation stage }\end{array}$ & 4819 & 4706 & 4615 & 4713 \\
\hline $\begin{array}{l}T_{6}: 1.5 \% \text { potassium silicate at Tillering } \\
\text { and PI stage }\end{array}$ & 4683 & 4630 & 4565 & 4626 \\
\hline $\begin{array}{l}\mathrm{T}_{7}: 1.5 \% \text { potassium silicate at Tillering, } \\
\mathrm{PI} \quad \text { and grain formation stage }\end{array}$ & 4743 & 4683 & 4577 & 4667 \\
\hline S. Em. \pm & 150 & 137 & 166 & 87 \\
\hline C. D. at $5 \%$ & 447 & 407 & 493 & 245 \\
\hline C.V. \% & 6.73 & 6.15 & 7.71 & 6.81 \\
\hline YxT & NS & NS & NS & NS \\
\hline
\end{tabular}

Table.3 Straw yield of kharif rice as influenced by foliar spray of potassium silicate

\begin{tabular}{|c|c|c|c|c|}
\hline \multirow[t]{2}{*}{ Treatments } & \multicolumn{4}{|c|}{ Straw Yield (kg/ha) } \\
\hline & 2015-16 & 2016-17 & 2017-18 & Pooled \\
\hline $\mathbf{T}_{1}$ : Control (No spray) & 5576 & 5611 & 5159 & 5449 \\
\hline $\begin{array}{l}T_{2}: 0.5 \% \text { potassium silicate at Tillering and } \\
\text { PI stage }\end{array}$ & 5926 & 5949 & 5541 & 5805 \\
\hline $\begin{array}{l}\mathrm{T}_{3}: 0.5 \% \text { potassium silicate at Tillering, } \mathrm{PI} \\
\text { and grain formation stage }\end{array}$ & 6102 & 6101 & 5826 & 6013 \\
\hline $\begin{array}{l}T_{4}: 1.0 \% \text { potassium silicate at Tillering and } \\
\text { PI stage }\end{array}$ & 6229 & 6256 & 5970 & 6152 \\
\hline $\begin{array}{l}T_{5}: 1.0 \% \text { potassium silicate at Tillering, } P I \\
\text { and grain formation stage }\end{array}$ & 6491 & 6491 & 6444 & 6475 \\
\hline $\begin{array}{l}\mathrm{T}_{6}: 1.5 \% \text { potassium silicate at Tillering and } \\
\text { PI stage }\end{array}$ & 6434 & 6511 & 6418 & 6454 \\
\hline $\begin{array}{l}\mathrm{T}_{7}: 1.5 \% \text { potassium silicate at Tillering, } \mathrm{PI} \\
\text { and grain formation stage }\end{array}$ & 6505 & 6559 & 6419 & 6495 \\
\hline S. Em. \pm & 181 & 201 & 235 & 117 \\
\hline C. D. at $5 \%$ & 537 & 596 & 698 & 329 \\
\hline C.V. \% & 5.85 & 6.46 & 7.87 & 6.60 \\
\hline YXT & NS & NS & NS & NS \\
\hline
\end{tabular}


Table.4 Effect of foliar spray of potassium silicate on economics of different treatments (av. of three year)

\begin{tabular}{|l|c|c|c|c|c|c|}
\hline Treatments & $\begin{array}{c}\text { Grain } \\
\text { yield } \\
\text { (kg/ha) }\end{array}$ & $\begin{array}{c}\text { Straw } \\
\text { yield } \\
\text { (kg/ha) }\end{array}$ & $\begin{array}{c}\text { Total cost of } \\
\text { cultivation } \\
\text { (Rs./ha) }\end{array}$ & $\begin{array}{c}\text { Gross } \\
\text { income } \\
\text { (Rs./ha) }\end{array}$ & $\begin{array}{c}\text { Net } \\
\text { income } \\
\text { (Rs./ha) }\end{array}$ & BCR \\
\hline $\mathbf{T}_{\mathbf{1}}:$ Control & 3992 & 5449 & 40700 & 76220 & 35520 & 1.87 \\
\hline $\begin{array}{l}\mathbf{T}_{\mathbf{2}}: \mathbf{0 . 5} \% \text { potassium silicate at } \\
\text { Tillering and PI stage }\end{array}$ & 4173 & 5805 & 41990 & 80011 & 38021 & 1.91 \\
\hline $\begin{array}{l}\mathbf{T}_{\mathbf{3}}: \mathbf{0 . 5} \% \text { potassium silicate at } \\
\text { Tillering, PI and grain formation stage }\end{array}$ & 4286 & 6013 & 42635 & 82326 & 39691 & 1.93 \\
\hline $\begin{array}{l}\mathbf{T}_{\mathbf{4}}: \mathbf{1 . 0} \% \text { potassium silicate at } \\
\text { Tillering and PI stage }\end{array}$ & 4391 & 6152 & 42640 & 84315 & 41675 & 1.98 \\
\hline $\begin{array}{l}\mathbf{T}_{\mathbf{5}}: \mathbf{1 . 0} \% \text { potassium silicate at } \\
\text { Tillering, PI and grain formation stage }\end{array}$ & 4713 & 6475 & 43610 & 90124 & 46514 & 2.07 \\
\hline $\begin{array}{l}\text { T: } \mathbf{T} \text { :5 \% potassium silicate at } \\
\text { Tillering and PI stage }\end{array}$ & 4626 & 6454 & 43290 & 88751 & 45461 & 2.05 \\
\hline $\begin{array}{l}\mathbf{T}_{\mathbf{7}}: \mathbf{1 . 5} \% \text { potassium silicate at } \\
\text { Tillering, PI and grain formation stage }\end{array}$ & 4667 & 6495 & 44585 & 89495 & 44910 & 2.01 \\
\hline
\end{tabular}

Selling price: Rice grain: 15 Rs./kg, Rice straw: 3 Rs./kg

Straw yield of rice increase up to the tune of 18.83, 18.44 and 19.20 per cent under the treatment $\mathrm{T}_{5}, \mathrm{~T}_{6}$ and $\mathrm{T}_{7}$, respectively. The improvement in straw yield of rice may be because of silicon is responsible to control stometal activity, photosynthesis and water use efficiency which ultimately results in better vegetative growth and straw yield. This is in conformation with the finding of Ahmad et al., (2007) and Surapornpiboom et al., (2008).

\section{Economics}

Among the different foliar application of potassium silicate, $1.5 \%$ potassium silicate at tillering, PI stages and grain formation stage recorded maximum total cost of cultivation (Rs. 44585/ha) followed by treatment $\mathrm{T}_{5}$ (Rs. 43610/ha) and $\mathrm{T}_{6}$ (Rs. 43290/ha). However, maximum gross income (Rs. 90124/ha), net income (Rs. 46514/ha) and B: C ratio (2.07) was incurred under the foliar spray of potassium silicate $1.0 \%$ at tillering, PI and grain formation stage, which was followed by treatments $T_{6}$ and $T_{7}$. The increase in income and cost benefit ratio under the application of potassium silicate may be due to increase the grain and straw yield under the same treatment.

From the above study it can be concluded that foliar application of potassium silicate 1.0 percent at tillering, panicle initiation and grain formation stage was recorded maximum panicle length, panicle weight, number of grain per panicle and weight of grain per panicle, grain yield, straw yield, gross and net income as well as benefit cost ratio. The above mentioned practices may be recommended for enhancing the productivity of rice under South Gujarat region.

\section{References}

Ahmad A, Afzal M, Ahaad A U H and Tahir A. 2013. Effect of foliar application of silicon on yield and quality of rice (Oryza sativa L.) Cercetari Agronomic in Moldova 155(3):21-28.

Ahmad F, Rahatullah, Aziz T, Maqsood M A, 
Tahir M A and Kanwal S. 2007. Effect of silicon application on wheat (Triticum asetivum L.) growth under water deficiency stress. Emirates Journal of Food Agriculture 19 (2):01-7.

Brunings A M, Datnoff L E, Ma J F, Mitani N, Nagamura Y, Rathinosabapathi B and Kirst M. 2009. Differential gene expression of rice in response to silicon and rise blast fungus Magnaporthe oryzae. Annals of Applied Biology 155:161-70.

Epstein E. 1999. Silicon. Annual Review: Plant Physiology and Plant Molecular Biology 50:641-664.

Gomez K A and Gomez A A. (1984). Statistical Procedure for Agricultural Research. Jhon Wiely and Sons, New York pp: 139-264.

Joseph E K, 2009. Assessing the silicon status of rice (Oryza sativa). M.Sc. thesis (unpublished) Department of Environmental and Soil Science, Louisiana State University and Agriculture and Mechanical Collage.

Liang Y C, Sun W C, Si J and Romheld V. 2005. Effect of foliar and root applied silicon on the enhancement of induced resistance to powdery mildew in Cucumis sativus. Plant Pathology 554: 678-85.

Malidareh A G. 2011. Silicon application and nitrogen on yield and yield component in rice in two irrigation systems. Academy of Science Engineering and Technology 78: 88-95.

Ma J F and Takahashi E. 2002. Soil fertilizer and plant silicon research in Japan. Elsevier Science, Amsterdam.

Ma J F, Mitani N, Nagao S, Konishi S, Tamai K, Iwashita $\mathrm{T}$ and Yano M. 2004. Characterization of silicon uptake system and molecular mapping of the silicon transporter gene in rice. Plant Physiology 136: 3284-89.

Ma J F, Tamai K, Yamaji N, Mitani N, Konishi
S, Katsuhara M, Fujiwara T and Yano M. 2007. An efflux transporter of silicon in rice. NATURE 448: 5964.

Mobasser H R, Malidarh G A and Sedghi H. 2008. Effect of silicon application to nitrogen rate and splitting on agronomic characteristics of rice (Oryza sativa L.) Silicon in Agriculture: $4^{\text {th }}$ International Conference 26-31 October, South Africa: 76.

Prakash N B, Chandrashekar N, Mahendra C, Patil S U, Thippeshappa G N and LaaneH M. 2011. Effect of foliar spray of soluble silicic acid on growth and yield parameters of wetland rice in hilly and coastal zone soils of Karnataka. Journal of Plant Nutrition 34: 1883-93.

Rodrigues F A, Datnoff L E, Korndorfer G H, Seebold K W and Rush M C. 2001. Effect of silicon and host resistance on sheath bight development in rice. Plant Disease. 85: 827-32.

Richond K E and Sussman M. 2003. Silicon: The non-essential beneficial plant nutrient. Current Opinion in Plant Biology 6: 26872.

Shashidhar H E, Chandrashekhar N, Narayanaswamy C, Mehendra A C and Prakash N B. 2008. Calcium Silicate as silicon source and its interaction with nitrogen in aerobic rice. Silicon in Agriculture: $4^{\text {th }}$ International Conference 26-31 October, South Africa, 93.

Singh K K and Singh K. 2005. Effect of N and Si on growth, yield attributes and yield of rice in alfisols. International Rice Research Notes 12: 40-41.

Surapornpiboom P, Julsrigival S. Senthong C. and Karladee D. 2008. Effect of silicon on upland rice under drought condition. Journal of Natural Science 7 (1): 16371.

\section{How to cite this article:}

Shah. K. A., Prabhu Nayaka and Lad. A. N. 2020. Response of Transplanted Paddy to Foliar Spray of Silicon in South Gujarat, India. Int.J.Curr.Microbiol.App.Sci. 9(05): 1051-1057. doi: https://doi.org/10.20546/ijcmas.2020.905.115 